\title{
Teacher's Strategy in Instilling Disciplined Characters in Class IV Students at SDN 2 Kalijaga
}

\author{
*Zaepi Aspiani, Darmiany, Husniati \\ Elementary School Teacher Education Study Program, FKIP, University of Mataram \\ *Corresponding Author e-mail: viaasvia0@gmail.com
}

Received: January 2022; Revised: January 2022; Published: January 2022

\begin{abstract}
The character of discipline can be interpreted as an attitude of obedience, submission and obedience to various applicable provisions and regulations. With a disciplined character, students are expected to become more responsible individuals, accustomed to something that makes them develop, do things on time and obey the values and rules that apply wherever they are. To achieve this goal, the teacher in this case really needs a strategy in its efforts. This study aims to describe the teacher's strategy in instilling the disciplined character of fourth grade students at SDN 2 Kalijaga. This research is a descriptive qualitative research with the type of phenomenology. The subjects in this study were the principal of SDN 2 Kalijaga, fourth grade teachers, and fourth grade students with the object of research being the teacher's strategy. Data were collected by means of interviews, observation and documentation. Data analysis was carried out using the Miles and Huberman model technique, namely data reduction, data presentation and conclusion drawing. The validity of the data was tested by using triangulation of sources and triangulation of data collection techniques. As for in this study, there are several strategies applied by teachers, namely integration in learning, establishing school rules, holding scout extracurriculars, exemplary values from teachers, giving sanctions/punishments, making policies in the form of new programs such as a joint prayer program in the field before start learning and picket schedule for the cleanliness of the school environment.
\end{abstract}

Keywords: Teacher Strategy, Character, Discipline, Elementary School

How to Cite: Aspiani, Z., Darmiany, D., \& Husniati, H. (2022). Teacher's Strategy in Instilling Disciplined Characters in Class IV Students at SDN 2 Kalijaga. Prisma Sains : Jurnal Pengkajian Ilmu dan Pembelajaran Matematika dan IPA IKIP Mataram, 10(1), 48-56. doi:https://doi.org/10.33394/j-ps.v10i1.4746

https://doi.org/10.33394/j-ps.v10i1.4746

Copyright $\odot$ 2022, Aspiani et al This is an open-access article under the CC-BY License.

\section{INTRODUCTION}

Education is expected to be able to educate the next generation of the nation, however, education does not only educate the nation, but in education it must also contain character education (Wahono, 2018). However, in this current era, education prioritizes knowledge and neglects to inculcate moral and ethical values in the nation's generation. That is why the importance of education is instilled from an early age, because character education is very important for the formation of ethics, morals and individual morals at the next level to make individuals better (Tyas, et al., 2020). Strengthening character education in the current era is an important thing to do considering the many events that indicate a moral crisis both among children, adolescents, and parents (Sultonurohmah, 2017). Therefore, strengthening character education needs to be carried out as early as possible starting from the family environment, school, and extending into the community. One of the character values that need to be developed is discipline (Kurniawan, 2016). The value of the character of discipline is very important for humans to have so that other good character values emerge. The importance of strengthening the values of disciplined character is based on the reason that there are now many deviant behaviors that are contrary to disciplinary norms (Utami and Prasetyo, 2021). Other undisciplined behavior, for example, is littering, parking not in a predetermined place, 
not complying with building permits, and so on. The existence of such violating behavior indicates that there is no public awareness (Unwanullah and Zuchdi, 2017; Yani et al., 2020).

Discipline is an absolute necessity in childhood considering that this period is the most effective period for the formation of children's behavior (Aulina, 2013). Every child has the potential to understand the rules that develop at every stage of his life. Discipline is needed to help children's personal and social adjustments (Yunita and Rofiyarti, 2017). Through discipline children can learn to behave in an approved way and in return they can be easily accepted by their social environment (Septiani, et al., 2021).

In order to foster good behavior towards students, schools usually make rules known as discipline. The existence of this school order is a guideline to tell students which behavior is justified and which behavior is not (Susanto, 2017). This shows that the rules in the school aim to guide and limit student behavior so that it tends to be in a better direction. Examples include time discipline, children must obey the right time to go to and from school, study, and other routine activities. Character education is an important thing that must be instilled in the younger generation of the nation's successors (Hubbi, et al., 2020).

Discipline character is very important to be instilled in students (Sultonurohmah, 2017; Zafirah, et al., 2018). According to Yustria (2021), public elementary schools have implemented the professionalism of classroom teachers in instilling the disciplined character of students well. However, students are less than optimal in applying the discipline character education that has been given by the teacher. For example, there are still students who do not obey the rules at school. Therefore, it is important for a classroom teacher to know what strategies are used to instill disciplined characters in students and what are the inhibiting factors in forming disciplined characters in students.

Based on initial observations made in the fourth grade of SDN 2 Kalijaga, Aikmel District, East Lombok, West Nusa Tenggara, the researchers found that most of the fourth grade students had good disciplined characters. This can be seen from students who obey the rules, such as at the beginning of the arrival of students to school, where students arrive at school before the appointed time by wearing neat uniforms, and when the class bell rings, all students enter the classroom in an orderly manner and pray before starting the lesson.

According to Navia and Yulia (2017) the level of student discipline and concentration of student learning is still very low. There are still many students who are not disciplined in time to study such as there are still many students who date are not on time in learning, there are still many students who are truant, many students do not complete assignments on time (Febrianti and Rachmawati, 2018; Matussolikhah and Rosy, 2021). Another problem that can be seen is that there are still many students who violate the rules and are not noisy in the classroom. Good learning discipline will be able to improve student learning outcomes. There are still quite a lot of students who do not concentrate in the teaching and learning process. When the teaching and learning process takes place, students do not fully pay attention to the teacher in front of the class explaining the lesson, students are busy with their own activities, some are whispering with their seatmates and some are paying close attention to the teacher but their minds are not fully concentrating on the current lesson. learned is explained by the teacher (Sari and Gifts, 2017).

Seeing the importance of discipline in learning, the teacher's task is not only to teach knowledge but in order to foster and educate students so that through learning by applying a disciplined attitude, students are expected to practice noble in their daily lives (Jeumpa, 2020). All of that becomes an absolute obligation for teachers, families and society. Thus, a teacher needs to use strategies in learning activities. Expectations from the use of this strategy can obtain maximum output and have noble character. Students' morals at school are largely determined by the application of discipline (Hasbullah, et al., 2019). 
Teachers can be said to be important actors in education. This is because teachers have the opportunity to interact more and more often with students in the implementation of learning. With this opportunity, teachers are expected to be able to form students who are not only successful in cognitive terms but must also be balanced with their affective abilities as well. Therefore, according to Ramdani, et al (2021) a teacher is not enough for the transfer of knowledge (transferring knowledge) from the outside, but also the transfer of value (transferring values) from the inside. This combination of external and internal things will help strengthen the building of knowledge, morals, or the character of students in facing their future.

Every teacher who plays a role in instilling a disciplined character in each individual student must have a strategy in his efforts, as a form of innovation and motivation to achieve a goal. In this case, the strategy is used as a tool so that guidance and inculcation of disciplined character in students become more focused or even on target.

The strategy applied in an effort to inculcate the disciplined character of students is not merely used as a rule that is only intended for students or programs that are required to be followed. However, there is also a need for initiatives in the form of good examples from the school environment, such as teachers or other staff who must be able to be role models for each student to mobilize and convince students to do what has been planned to achieve a goal, namely to form a disciplined character. learners. This is in line with the opinion of Suriansyah (2015), that there are several strategies applied by teachers in instilling the character of students, namely direct example every day, habituation through direct involvement in learning, and touching the heart with words of wisdom. Another opinion by Wuryandani, et al (2014) also states that the strategy launched in an effort to support the success of student discipline character education is to procure character education programs, establish school rules and class rules, perform dhuha prayers and dhuhur prayers in congregation, create affective posts in the community. each class, monitor the disciplinary behavior of students at home through daily activity notebooks, provide affective messages in various corners of the school that are easily seen by school residents, involve parents and school committees in disciplinary character education, and create a conducive classroom climate as a laboratory for students to behave disciplined. This study aims to describe the teacher's strategy in instilling the disciplined character of fourth grade students at SDN 2 Kalijaga.

\section{METHOD}

The approach in this study is a descriptive qualitative approach with the type of phenomenology. Data collection techniques in this study are in the form of words or information through interviews, documentation and observations in accordance with phenomena or events in a place, as they are, so that the data are not in the form of numbers or symbols. The data analysis technique uses the model from Miles and Huberman, namely data reduction, data presentation, and drawing conclusions. The validity test of the data was analyzed by data triangulation technique. The triangulation technique in this study uses data triangulation and source triangulation, carried out by checking the data obtained through the research subject.

The method according to Sugiyono (2016) is as a scientific way to obtain data with certain goals and uses. The data obtained through this research is empirical data that has certain criteria, namely valid. Valid in the sense that the data can show the degree of accuracy between the data that has been collected by the researcher and the actual situation.

Descriptive research does not provide treatment or manipulation of the variables to be studied, but describes how the real conditions or what they are for what is being studied. The reason for using this type of descriptive qualitative research in this study is because based on 
the existing title, the researcher will describe or describe how the teacher's strategy in shaping the disciplined character of fourth grade students at SDN 2 Kalijaga, Aikmel, East Lombok, West Nusa Tenggara.

\section{RESULTS AND DISCUSSION}

\section{The Discipline Character of Class IV Students at SDN 2 Kalijaga}

Discipline character is an attitude that is owned by someone about how to obey various regulations that exist in the school environment through guidance and education within the school itself. Discipline character is one of the most important characters to have in an effort to cultivate character education. Character education is a process carried out to develop good values in students. The intended process is to provide guidance to students to become fully human beings with character in all dimensions, be it heart, mind, body, taste or intention (Mumpun, 2018).

Maisaro, et al (2018) suggest that character education is closely related to management or institutional management. What is meant in this case is how character education is planned and implemented in the activities that exist within the institution. The management includes what values need to be instilled, learning, assessment, how educators and education staff are. From this theory, it was found that there was a match with the planning of programs that would be implemented or integrated with learning, could be well received by students so that it had an impact on the success of planting the disciplined character of students.

The character of discipline according to Pedha (202) is defined as attitudes and behaviors that arise as a result of training or the habit of obeying rules, laws, or orders. Based on the research data that has been presented, the informants stated that the character of the discipline is very important for each individual student to have. Because if the character of this discipline is properly implanted and applied properly, it will also have a positive impact on the lives of students later.

The results of interviews, observations and documentation show that the disciplined character of fourth grade students at SDN 2 Kalijaga can be said to be good. This can be seen from several aspects, ranging from time discipline, uniform discipline, learning discipline, and how students respect and obey their teachers.

\section{Time discipline}

Time discipline is defined as an attitude in which students have obedience and obedience to a predetermined time. The time discipline possessed by the fourth grade students of SDN 2 Kalijaga is very good, because the researchers found that all students came to school earlier than the predetermined hours, especially for students who had class picket turns. In addition, when the bell to signal the start of learning rang, students swiftly headed to the field and lined up neatly to carry out prayers together. Likewise, regarding the time for collecting assignments, class IV students always collect them at the appointed time.

Time discipline is important for students to have, because through this time discipline students can use time well, do things on time, so that they can change students' lives to be more efficient and effective.

\section{Discipline in uniform}

Discipline in uniform is one of the rules that exist in the school environment, and must be obeyed by students. From this uniform, the nature of discipline can be seen from the students. So related to this, the researchers found a uniform discipline that was quite good overall in class IV SDN 2 Kalijaga, even though they had used the uniform according to the day based on existing regulations, there were still students who were indifferent to selftidiness such as not wearing a belt and not wearing a belt. shirt into pants for men, and not wearing a hat. 


\section{Discipline of study}

Learning discipline is one of the manifestations of compliance and obedience to applicable regulations. The students in grade IV at SDN 2 Kalijaga have been able to maintain order in learning well. This can be seen from how students carry out class agreements, such as not being allowed to talk when the teacher explains learning, not saying dirty things, and respecting friends and teachers. Although there are still some students who like to disturb the concentration of friends while studying by being invited to talk. However, there are always students who try to remind them to be quiet and pay attention to the teacher in a good way and say politely. The same thing happens when the teacher provides exercises during learning.

\section{Respect and obey the teacher}

Respect and obedience to teachers must be applied in everyday life, both when meeting at school and on the street. This is because it is the teacher who educates and teaches various sciences, so that we become people who understand many things in the lesson. The respect and obedience of students at SDN 2 Kalijaga can be seen when students meet and pass the teacher, they will immediately greet and shake hands. Students always knock on the door and greet when they want to enter the classroom, teacher's room, and principal's room, listen to the teacher when explaining learning materials, and always ask for permission when going out of class. All the disciplinary characters that have been seen by researchers are the result of the implementation of good character education by existing educators.

\section{Teacher's Strategy in Instilling Disciplined Characters in Class IV Students of SDN 2 Kalijaga}

Strategy can be interpreted as a plan on ways to utilize and use existing potential and facilities to increase the effectiveness and efficiency of an activity target (Yustiqvar, et al., 2018). The strategies used by teachers at SDN 2 Kalijaga in an effort to instill the disciplined character of class IV students, are integration in learning, establishing school rules and class agreements, procuring scout extracurriculars, exemplary, imposing sanctions/punishments and making several new policies.

The strategy applied at SDN 2 Kalijaga has similarities with the strategy according to Masrifatin (2019) that there are several strategies that are used comprehensively in an effort to cultivate the character of students, namely (1) Inculcation of values, is one strategy by placing an emphasis on inculcating values. in students. (2) Value exemplary, is the most widely used strategy, because inculcating behavior (behavior) requires a figure who becomes a model that students can find in the surrounding environment. (3) Facilitation, is the provision of opportunities to students, with the activities carried out that can have a positive impact on the personality development of students. As in learning activities and extracurricular activities. In addition, Mutmainah, et al (2018), that there are several strategies applied by teachers in instilling the character of students, namely direct example every day, habituation through direct involvement in learning, and touching the heart with words of wisdom. The following is an explanation of the teacher's strategy in instilling the disciplined character of students at SDN 2 Kalijaga:

\section{Integration in learning}

The teacher always gives a time limit regarding the collection of school assignments. Furthermore, teacher using literary and non-fiction works to share inspirational stories. This is not always done by the teacher, but if there are students who look bored or lazy during the learning process, the teacher will only ask about the obstacles they face and provide motivation by linking the learning materials so that they students will return to the spirit of learning. 
Efforts to instill disciplined character in students are easiest to do during the learning process. Because on this occasion, teachers and students have the opportunity to communicate directly. The deadline for collecting assignments is done by the teacher to train time discipline and a sense of responsibility for students for the work given by the teacher.

\section{Determination of school rules and class agreements}

Class rules and agreements made are not merely a formality in the form of policies and of course made with a purpose. Through the making of these rules, it is hoped that students will have good discipline by obeying and implementing applicable regulations. In relation to this, it was found that each class had affixed a board with rules written on it so that students could always see, remember and finally be able to carry out the existing rules properly while in the school environment. It can be seen that almost all students carry out the rules well from the initial arrival of students at school, neatness, and how students are during the learning process.

\section{Procurement of extracurricular programs}

SDN 2 Kalijaga has extracurricular activities related to inculcating students' discipline character, namely, scout extracurricular that requires all members to be disciplined individuals. This is reflected in behavior that is obedient to the leadership, tolerance, cooperation and always on time in every situation. From this scouting activity, it is expected that students have the discipline inherent in themselves so that the attitudes and behaviors carried out are not considered a burden, on the contrary, they will consider a burden if they do not act as disciplined as they should.

\section{Value exemplary}

Value exemplary is the strategy most emphasized by the teacher in an effort to cultivate the disciplined character of fourth grade students. This is because the teacher believes that to instill the character of discipline, it will not be realized if only the theory is conveyed but must also be exemplified by the good things. Considering that teachers are also the closest example to students who are still unable to think abstractly, such as the opinion of Jean Piaget in his theory which states that children at elementary school age with an age range of 7-11 years are in the understanding phase in logical thinking but do not understand abstract concepts. . The examples of exemplary values that are carried out are: (1) Teachers come to school on time: Observations show that all teachers have given good examples of time discipline to students. All the teachers were already at the school at the appointed time even before the class bell rang. Teachers who arrive at school will greet and shake hands with other teachers who have already arrived at school. (2) Always present in every lesson: Every teacher who has a schedule in class is always present, except in certain very urgent circumstances. The teacher in question will give permission and ask for help from other teachers to give assignments that have been prepared and supervise students. (3) Be present in class on time: Every teacher is always present in class on time according to existing regulations. (4) The learning process is in accordance with the time allocation: The learning process is always carried out according to the predetermined allocation.

\section{Giving punishment (sanctions/punishments)}

Punishment is a repressive educational tool that aims to make children aware of the good things so that they get used to being orderly with existing regulations. The punishment given to students is also expected to be able to bring students to become more responsible individuals in everything that will be done. The punishment will be given by the teacher to students who violate the rules or class agreements that have been made. For example: the teacher will punish students for picking up trash or cleaning up a dirty field if they are late for 
school. In addition, students will be given sanctions to re-create the assignments given if they are not collected.

\section{Make a new policy in the form of a school program.}

Another strategy used in an effort to instill the disciplined character of students is to make a new policy in the form of a program. Such as: making a joint prayer program in the field before entering class to start learning and making a schedule for picket cleaning the school field, where students who have picket turns are strived to always arrive earlier than the picket schedule made.

The policies made aim to instill a disciplined character in students. With this policy, students are expected to have good time discipline character, so that they can use their time well and efficiently wherever they are.

\section{CONCLUSION}

Based on the results of the research and discussion that have been described, it can be concluded that the character of discipline in grade IV at SDN 2 Kalijaga is well embedded. This can be seen from various aspects of discipline in the school environment. Such as: (a) Time discipline, all students come to school earlier than the specified hour, especially for students who have a class picket turn, when the bell that signals the start of learning rings, students go to the field and line up neatly to carry out pray together. Likewise, regarding the time for collecting assignments, class IV students always collect them at the appointed time. (b) Discipline in uniform, uniform discipline is quite good overall and has used the uniform according to the day based on the existing regulations, it's just that there are still students who are indifferent to self-tidiness such as not wearing a belt and not putting clothes in their pants for boys. men, and not wearing a hat. (c) Discipline of learning, fourth grade students already have good learning discipline. This can be seen from how students carry out class agreements, such as not being allowed to talk when the teacher explains learning, not saying dirty things, and respecting friends and teachers. Although there are still some students who like to disturb the concentration of friends while studying by being invited to talk. However, there are always students who try to remind them to be quiet and pay attention to the teacher in a good way and say politely. (d) Respect and obedience to the teacher, Respect and obedience of students at SDN 2 Kalijaga can be seen when students meet and pass by the teacher, they will immediately greet and shake hands. Students always knock on the door and greet when they want to enter the classroom, teacher's room, and principal's room, listen to the teacher when explaining learning materials, and always ask for permission when going out of class.

In addition to the disciplined character of students, there are several strategies used in instilling the disciplined character of fourth grade students at SDN 2 Kalijaga, as follows: Integration in learning, namely by giving deadlines for each given task and using literary and non-fiction works to share inspirational stories. Determination of school rules and class agreements. Organize scout extracurricular activities. Exemplary values from teachers, through several examples, namely: Teachers come to school on time, are always present in every lesson, are present in class on time and carry out the learning process according to the time allocated. Giving sanctions/punishments, and Make a policy in the form of a new program such as a joint prayer program in the field before starting learning and a picket schedule for the cleanliness of the school environment.

\section{RECOMMENDATION}

Teachers must be able to instill character education when teaching, one of which is disciplined character education. The learning strategy carried out by the teacher is very 
important to implement. Hopefully other research can describe learning strategies and models to improve student learning outcomes.

\section{REFERENCES}

Aulina, C. N. (2013). Penanaman disiplin pada anak usia dini. PEDAGOGIA: Jurnal Pendidikan, 2(1), 36-49.

Febrianti, L., \& Rachmawati, L. (2018). Pengaruh Kecerdasan Emosional dan Disiplin Belajar terhadap Hasil Belajar Siswa di SMA Negeri 3 Nganjuk. Jurnal Pendidikan Ekonomi (JUPE), 6(2).

Hasbullah, H., Juhji, J., \& Maksum, A. (2019). Strategi belajar mengajar dalam upaya peningkatan hasil belajar pendidikan agama islam. EDURELIGIA: Jurnal Pendidikan Agama Islam, 3(1), 17-24.

Hubbi, U., Ramdani, A., \& Setiadi, D. (2020). Integrasi Pendidikan Karakter kedalam Pembelajaran Pendidikan Agama Islam dan Pendidikan Kewarganegaraan di Era Milenial. JISIP (Jurnal Ilmu Sosial dan Pendidikan), 4(3).

Jeumpa, N. (2020). Strategi guru dalam meningkatkan disiplin belajar aqidah akhlak siswa. Serambi Tarbawi, 8(1), 99-112.

Kurniawan, F. (2016). Analisis Penerapan Budaya Sekolah Dalam Pembentukan Karakter Disiplin Siswa Di Kelas III Sd N 2 Blunyahan.

Maimunah, M., Aslamiah, A., \& Suriansyah, A. (2018). The integration of sentra-based Learning and involvement of family program at early childhood in developing character building (Multi Case at PAUD Mawaddah and PAUD Alam Berbasis Karakter Sayang Ibu Banjarmasin, Indonesia). European Journal of Education Studies.

Maisaro, A., Wiyono, B. B., \& Arifin, I. (2018). Manajemen program penguatan pendidikan karakter di sekolah dasar. JAMP: Jurnal Administrasi dan Manajemen Pendidikan, 1(3), 302-312.

Masrifatin, Y. (2019). Strategi Pembudayaan Karakter Pada Pendidikan Dasar Islam. JURNAL LENTERA: Kajian Keagamaan, Keilmuan dan Teknologi, 18(1), 2339.

Matussolikhah, R., \& Rosy, B. (2021). Pengaruh Disiplin Belajar dan Gaya Belajar terhadap Hasil Belajar Siswa dalam Pembelajaran Daring di Masa Pandemi Covid-19. Prima Magistra: Jurnal Ilmiah Kependidikan, 2(2), 225-236.

Navia, Y., \& Yulia, P. (2017). Hubungan Disiplin Belajar dan Konsentrasi Belajar terhadap Hasil Belajar Matematika Siswa. PYTHAGORAS: Journal of the Mathematics Education Study Program, 6(2).

Pedha, M. P., Sumarti, E., \& Rachman, A. K. (2021, September). NILAI-NILAI PENDIDIKAN KARAKTER DALAM KUMPULAN CERPEN INSPIRATIF KARYA RORA RIZKI WANDINI, M. PD. I, RACHBEL, YURA, MAYRA. In Prosiding Seminar Nasional Sastra, Lingua, Dan Pembelajarannya (Salinga) (Vol. 1, No. 1).

Ramdani, A., Jufri, A. W., Gunawan, G., Fahrurrozi, M., \& Yustiqvar, M. (2021). Analysis of Students' Critical Thinking Skills in terms of Gender Using Science Teaching Materials Based on The 5E Learning Cycle Integrated with Local Wisdom. Jurnal Pendidikan IPA Indonesia, 10(2), 187-199.

Sari, B. P., \& Hadijah, H. S. (2017). Meningkatkan disiplin belajar siswa melalui manajemen kelas. Jurnal Pendidikan Manajemen Perkantoran (JPManper), 2(2), 233-241.

Septiani, E., Erni, E., \& Izzatika, A. (2021). Hubungan Motivasi Belajar Ekstrinsik dan Disiplin Belajar dengan Hasil Belajar Matematika Peserta Didik di Sekolah Dasar. Pedagogi: Jurnal Pendidikan Dasar, 9(1). 
Sultonurohmah, N. (2017). Strategi penanaman nilai karakter jujur dan disiplin siswa. AlIbtida, 5(2), 1-21.

Suriansyah, A. (2015). Strategi kepemimpinan kepala sekolah, guru, orang tua, dan masyarakat dalam membentuk karakter siswa. Jurnal cakrawala pendidikan, 34(2).

Susanto, A. (2017). Proses Habituasi Nilai Disiplin Pada Anak Usia Dini Dalam Kerangka Pembentukan Karakter Bangsa. Sosio Religi: Jurnal Kajian Pendidikan Umum, 15(1).

Tyas, E. H., Sunarto, S., \& Naibaho, L. (2020). Building Superior Human Resources through Character Education. TEST Engineering \& Management, 83, 11864-11873.

Unwanullah, A., \& Zuchdi, D. (2017). Pendidikan akhlak mulia pada sekolah menengah pertama Bina Anak Soleh Tuban. Jurnal Pembangunan Pendidikan: Fondasi dan Aplikasi, 5(1), 1-13.

Utami, F., \& Prasetyo, I. (2021). Pengasuhan keluarga terhadap perkembangan karakter disiplin anak usia dini. Jurnal Obsesi: Jurnal Pendidikan Anak Usia Dini, 5(2), 17771786.

Wahono, M. (2018). Pendidikan Karakter: Suatu Kebutuhan Bagi Mahasiswa di Era Milenial. Integralistik, 29(2), 145-151.

Wuryandani, W., Maftuh, B., \& Budimansyah, D. (2014). Pendidikan karakter disiplin di sekolah dasar. Jurnal Cakrawala Pendidikan, 33(2).

Yani, S., Kusen, K., \& Khair, U. (2020). Kebijakan Sekolah Dalam Penerapan Karakter Disiplin Siswa Di SDN 77 Rejang Lebong. Andragogi: Jurnal Pendidikan Islam dan Manajemen Pendidikan Islam, 2(3), 99-115.

Yunita, A., \& Rofiyarti, F. (2017). Penerapan disiplin sebagai bentuk pembinaan pendidikan karakter terhadap anak usia dini. Pedagogi: Jurnal Anak Usia Dini dan Pendidikan Anak Usia Dini, 3(3c).

Yustiqvar, M., Hadisaputra, S., \& Gunawan, G. (2019). Analisis penguasaan konsep siswa yang belajar kimia menggunakan multimedia interaktif berbasis green chemistry. Jurnal Pijar Mipa, 14(3), 135-140.

Yusutria, S. (2021). Profesionalisme Guru dalam Menumbuhkan Nilai Karakter Siswa Berbasis Nilai-Nilai Budaya 5S (Senyum, Sapa, Salam, Sopan, Santun) di SMK 1 Muhammadiyah Kasihan Bantul Yogyakarta. Jurnal Pendidikan Islam, 12(2), 171188.

Zafirah, A., Agusti, F. A., Engkizar, E., Anwar, F., Alvi, A. F., \& Ernawati, E. (2018). Penanaman nilai-nilai karakter terhadap peserta didik Melalui permainan congkak sebagai media pembelajaran. Jurnal Pendidikan Karakter, 8(1). 